\title{
11. What explains the popular support for basic income?
}

\author{
Miska Simanainen and Olli Kangas
}

\section{INTRODUCTION}

There is growing interest in understanding the popular support for basic income in Finland and globally. On the one hand, researchers have tried to evaluate the level of support in different countries, and, on the other hand, to explain the variation of support within populations. In addition to scientific curiosity, there are practical reasons for surveying population support. These reasons are closely linked to politics and policymaking: for example, political parties aim to understand the opinions of the electorate to frame their political agenda in a way that resonates with opinions among their possible voters and maximises their political support in elections.

During the last two decades, support for basic income has been stable in Finland. Surveys carried out before the Finnish basic income experiment showed that about 60 to 70 percent of Finns were in favour of universal basic income (Airio et al., 2016; Andersson and Kangas, 2005). However, recent studies on popular support have provided highly divergent results. Differences in the results of separate surveys are likely related to differences in the definitions of basic income given in the questionnaires. Previous research has shown that there tends to be a substantial framing effect on the level of support for policy issues (Rasinski, 1989). Moreover, such general questions as 'Are you in favour of or against basic income?' and 'Is basic income good or bad?' tend to produce much higher support levels than more specific questions that aim to explain the content of the basic income model (Pulkka, 2018). One obvious feature of general survey questions on basic income is that they do not give any indication to the respondent about the possible costs of implementing basic income. In some Finnish surveys, the respondents were given more detailed information about the costs and tax levels needed to finance the benefit. Such more-detailed information decreased the support levels to lower than 30 percent (Airio et al., 2016). 
As regard public support for basic income, Finland is ranked in a middle position internationally. The 2016 wave of the European Social Survey (ESS) included a question about basic income. The scheme was described as a universal transfer that everyone receives from the state, regardless of any other sources of income. In the ESS survey, basic income was described as covering essential living costs and replacing many other social benefits. Meanwhile, the strongest support for basic income was found in Russia (73 percent) and Israel (65 percent), and the weakest support was found in Sweden, Switzerland and Norway (37, 35 and 34 percent, respectively). In Finland, 65 percent of the population supported the basic income model as worded in the ESS (Fitzgerald, 2017).

In their comparative study, Roosma and van Oorschot (2020) found that, in Europe, basic income is supported in countries with low levels of social spending and high levels of material deprivation. Parolin and Sjöland (2020) showed that in countries with high union density, support for basic income is lower than in countries with lower unionisation rates. Given these findings, Finland appears to be an interesting case: its social spending is one of the highest in the world, material and social deprivation among the lowest, the welfare state is rather generous, and the unionisation rate is the highest in Europe. However, support for basic income in Finland seems to be much higher than in many other countries.

In this chapter, we are interested in the underlying reasons for the support for basic income, that is, why some people are more inclined to favour and others to oppose universal and unconditional income transfers. In previous studies on the support for basic income, socio-economic and demographic factors, such as gender, age, education and income, and political affiliation have been shown to be important explanatory variables (Andersson and Kangas, 2004, 2005; Pulkka, 2018; Roosma and van Oorschot, 2020; Simanainen and Kangas, 2020). In our subsequent inspections, we extend the analysis by studying other potential determinants of basic income support. These include (1) income inadequacy and insecure employment relations, and (2) perceptions of the causes of social problems and specific opinions about basic income. We explore the above-mentioned potential explanatory factors by utilising survey data from two opinion surveys conducted after the Finnish experiment.

The study sheds light on the role of material conditions (income and employment) and attitudinal aspects in explaining basic income support within the Finnish population.

The rest of the chapter proceeds as follows. First, we present the theoretical motivation for our research questions and the survey data used in the empirical analyses. The empirical sections focus on different potential explanations for popular support. 
We analyse how income inadequacy and insecure employment relations are associated with the likelihood of supporting basic income. Then, we analyse how perceptions of 'deservingness' (whether individuals' social problems are the result of their own actions or rather of social structures) are linked to the popular support of basic income. Thereafter, we focus on the association between basic income support and specific opinions on the characteristics of basic income. In the final section, we summarise our findings and discuss their societal relevance.

\section{THEORETHICAL FRAMEWORK, OBJECTIVES AND METHODS}

\section{Income Inadequacy and Insecure Employment}

There are many doomsday prophesies that robots will take over human labour and that there will be massive disappearance of paid (human) work in the future (Frey and Osborne, 2017). The development of the digital mode of production has been seen to lead to mass unemployment. While the prophesies about the end of work may be too premature, the new digital economy will likely change the characteristics of employment in the future; for example, it has been calculated that one-third of the traditional jobs in Finland could disappear and be replaced by new types of employment (Pajarinen and Rouvinen, 2014). In other countries, this process may be even faster. Technological change may also lead to polarisation in labour markets: employment bifurcates into the expansion of low-paid and precarious employment on the one hand and high-skilled employment with secure positions on the other hand. Moreover, the share of middle-skilled routine jobs may diminish (for example, Frey and Osborne, 2017; Goos et al., 2010).

In his Global Labour Flexibility, Guy Standing (1999) analyses major trends in labour markets and concludes that flexibility means increasing insecurity that gradually threatens the sustainability of the entire production system. Standing $(2011,2016)$ further develops the idea of the 'precariat' as a dangerous class whose problems must be solved. There are two aspects to the problem of the precariat: the first pertains to the unsecure position between employment and under-employment, and the second to inadequate income protection that the class faces. Due to these problems, people in the precariat are volatile, may create instability in the society, and may become frustrated and easy prey for populist and extreme social and political movements, argues Standing. Thus, in a Polanyian sense (Polanyi, 2001 [1944]), a new social policy system is functionally needed to fix the problems of capitalism and prevent the economic system from destroying itself. The advocates of basic income see basic income 
as the new social policy system answering the problems created by technological change (Standing, 2016; see also Bregman, 2017).

Attitudes and opinions in general and attitudes toward the welfare state in particular are sensitive to individuals' positions in the social stratification system (Larsen, 2006; Roosma and van Oorschot, 2020; Svallfors, 2012). In this study, we hypothesise that those in insecure labour market positions are more likely to support universal basic income than those coping better or having more secure labour contracts. In the following empirical section, we aim to shed light on the potential association between insecure employment and popular support for basic income. In particular, we analyse whether there are any systematic differences in the opinions of those who have permanent jobs versus fixed-term employment contracts, and of those who are working full-time or part-time, or who have only zero-hour contracts. Furthermore, we analyse how people's perceptions of income adequacy are associated with their opinions on basic income.

\section{Values, Attitudes and Item-specific Opinions}

Values define what is good and bad in our society (Rokeach, 1973). There is a correspondence between values and attitudes, and in the transition from value preferences to various issue attitudes (Jacoby, 2006). However, purely based on individuals' value structures, we cannot say much about individuals' attitudes and opinions on more specific social questions (Zaller, 1992). Individuals can share the same values (such as freedom and happiness) but their opinions on practical social and political issues and, hence, on wished-for policy options may be very different. Therefore, we have to narrow our scope and step down from values to focus on attitudes on social matters and to more specific issue opinions.

Attitudes and opinions are more volatile and less stable over time than values, and they may change when new information and experiences are received. Attitudes are states of mind representing individuals' propensity to respond in a certain way to a given stimulus (for example in opinion surveys), whereas issue opinions are more specific, bound to a specific and more detailed question.

In our analyses, we assume that attitudes pertain to a more generic way of thinking about the reasons for becoming a welfare recipient. Van Oorschot and Halman (2000) distinguish between two general explanations or popular perceptions of why some individuals have fallen into poverty, whereas others have not (see also van Oorschot, 2000; Andersson and Kangas, 2004, 2005; Niemelä, 2008; van Oorschot et al., 2017). According to the first brand of explanations, 'individual blame', people face problems because they lack will-power. Oftentimes, also the welfare state is blamed: it is seen to create 
overly strong incentives for people not to take care of themselves, and as seducing people into idleness (for example, Murray, 1984).

The second category of explanations, 'social blame', pertains to a number of social injustices and social problems created by societal structures and changes. According to this line of thinking, the existing measures that the welfare state offers are not strong enough to help the poor out of poverty.

There is an abundance of more specific arguments presented in favour of and against basic income. The proponents of basic income regard it as a source of emancipation and real freedom (Van Parijs, 1995; Standing, 2017; Van Parijs and Vanderborght, 2017), solutions to various problems of precarious employment (Standing, 1999, 2011), and as a way to diminish bureaucracy and simplify the overly complicated and non-transparent 'jungle' of social benefits. Communitarians support basic income because they see that it would enhance voluntary work, facilitate activities in the third sector, and fortify their responsibilities toward fellow citizens (Etzioni and Platt, 2008). On the other side of the demarcation line, opponents are afraid of detrimental labour market effects - basic income would decrease labour supply (for a discussion, see Knotz, 2019). Moreover, there are arguments that the one-size-fits-all approach is not a good strategy: basic income does not take into consideration individual circumstances and therefore, on top of basic income, myriad other benefits and services would still be needed. Otherwise, those in the weakest positions would be left without adequate support. At the end of the day, basic income would not reduce bureaucracy; on the contrary, bureaucracy would increase (see, for example, De Wispelaere and Stirton, 2013).

Based on the aforementioned ways of reasoning about the characteristics of basic income, we develop a battery of item-specific questions to look into popular perceptions on the potential consequences of introducing a basic income (see Table 11A.1 in Appendix). In this study, we hypothesise that the two attitudinal dimensions, that is, individual and social blame, are systematically related to more detailed and item-specific opinions about basic income and, more importantly, to the popular support for introducing basic income in Finland.

\section{Data and Methods}

To find evidence on the research questions presented in the previous section, we utilise data from two survey studies. First, the subsection on income inadequacy and insecure employment draws on data from a population survey carried out via telephone from February-March 2020. The survey contains responses from 2500 respondents. The data sample is weighted by age, gender, and place of residence to represent the total Finnish population. Second, data on attitudes and item-specific opinions are from a thematic opinion survey 
conducted in the same period. The data include responses from a survey sample of 1002 respondents and represent the mainland Finnish population.

For descriptive analyses, we present cross-tabulations of the distribution of opinions for different survey questions. To study the associations between the variables, we utilise regression analysis. In the analyses, we control for the known demographic and socio-economic determinants of the variables and present the results only for our variables of focus. To squeeze the number of variables included in the analyses, we rely on factor analysis to determine whether it is meaningful to construct additive summative variables out of several survey questions. The validity of the additive summary variables is evaluated using Cronbach's alpha.

\section{EXPLAINING THE SUPPORT FOR BASIC INCOME IN FINLAND: EMPIRICAL EXPLORATIONS}

\section{Income Inadequacy and Insecure Employment}

A population survey conducted in early 2020 as part of the evaluation project of the Finnish basic income experiment explored the association between experienced income inadequacy and insecure employment relations and the support for basic income in Finland. According to the study, at the population level, the experience of inadequate household income was associated with support for basic income: the more difficult the respondent's perceived financial position was, the more likely he or she was to support the introduction of a basic income. About 43 percent of the respondents who indicated that they had no difficulties meeting their needs supported basic income. On the other hand, about 54 percent of those who had some difficulties in meeting their needs with household income, and about 74 percent of those who had major difficulties, reported supporting basic income (Simanainen and Kangas, 2020).

Among those who were employed, the type of employment contract was associated with attitudes toward basic income as well. Both part-time and fixed-term work contracts increased the probability of supporting basic income. About 44 percent of people with full-time and permanent work contracts supported the idea of introducing basic income in Finland. For those with a permanent but part-time contract, the share was 53 percent. Meanwhile, 58 percent of those with a fixed full-time contract supported basic income. Finally, the support rate for basic income was as high as 71 percent in the group with a fixed part-time contract (Simanainen and Kangas, 2020).

Table 11.1 presents a regression analysis of the association between income inadequacy and type of employment and the support for basic income with controls for gender, age, municipality group, labour market position, education, income and household type. We find statistically significant estimates 
for the association between income inadequacy and type of employment (fixed-term and part-time contracts) and support for basic income. Moreover, having a fixed contract is a stronger determinant of support than working part-time. With additional control variables included, the explanatory power of the models is about 5 percent. The relatively low explanatory power of the model motivates us to explore other potential explanatory factors for the support of basic income in the population.

Table 11.1 Regression analysis results on the determinants of support for basic income in Finland 2020: income inadequacy and insecure employment

\begin{tabular}{lcccc}
\hline & Coefficient & $p$-value & adj. $R^{2}$ & $N$ \\
\hline Type of employment (model 1) & & & & \\
Full-time, permanent (reference) & - & - & & \\
Full-time, fixed-term & 0.23 & 0.04 & & \\
Part-time, permanent & 0.09 & 0.54 & & \\
Part-time, fixed-term & 0.50 & 0.01 & & \\
Zero-hour contract & 0.34 & 0.27 & & \\
Inadequate income (model 2) & 0.24 & 0.01 & 0.06 & 2360 \\
\hline
\end{tabular}

Notes: In Model 1, explanatory variables include type of employment, income inadequacy, gender, age, municipality group, education, income and household size. Model 2 includes income inadequacy, gender, age, municipality group, labour market status, education, income and household size. The dependent variable is measured with the following survey question: 'What do you think about the following statement? A basic income should be introduced as a permanent part of the social security system in Finland: strongly agree (5), somewhat agree (4), neither agree nor disagree (3), somewhat disagree (2), strongly disagree (1) and cannot say (excluded from the analysis)'. Income inadequacy is measured with: 'Which of the following best describes your household income at present? We live comfortably on our current income or we are doing OK (0), we have difficulties or we are barely getting by (1), not sure (excluded)'.

\section{Deservingness: Individual or Social Blame?}

General opinions on the reasons why people have social and financial problems and need support from the welfare state are strongly related to more specific opinions on the welfare state, its characteristics, scope, size, and legitimacy. In Table 11.2, we present the six questions used in the opinion survey to measure respondents' views on the causes of unemployment: whether they are related to individual factors (own fault), or to various societal problems and structural 
changes in the society. Similarly, the respondents could express their opinions about why people are poor and if it is too easy to obtain social benefits.

Table $11.2 \quad$ Perceived causes for unemployment and poverty among the Finns in 2020

\begin{tabular}{|c|c|c|c|c|c|c|}
\hline & \multicolumn{3}{|c|}{ Causes of unemployment } & \multicolumn{3}{|c|}{ Causes of poverty } \\
\hline & $\begin{array}{l}\text { 1. Own } \\
\text { fault } \\
(\%)\end{array}$ & $\begin{array}{l}\text { 2. Societal } \\
\text { problems } \\
(\%)\end{array}$ & $\begin{array}{l}\text { 3. Structural } \\
\text { change }(\%)\end{array}$ & $\begin{array}{l}\text { 4. People do } \\
\text { not try hard } \\
\text { enough }(\%)\end{array}$ & $\begin{array}{c}\text { 5. Inadequate } \\
\text { basic security } \\
(\%)\end{array}$ & $\begin{array}{l}\text { 6. It is too easy } \\
\text { to live on social } \\
\text { benefits }(\%)\end{array}$ \\
\hline $\begin{array}{l}\text { Fully } \\
\text { disagree }\end{array}$ & 45.7 & 6.2 & 5.0 & 33.0 & 12.4 & 16.2 \\
\hline $\begin{array}{l}\text { Partially } \\
\text { disagree }\end{array}$ & 36.9 & 26.7 & 18.1 & 37.0 & 37.2 & 25.0 \\
\hline $\begin{array}{l}\text { Partially } \\
\text { agree }\end{array}$ & 13.5 & 49.8 & 56.5 & 22.4 & 33.6 & 35.0 \\
\hline $\begin{array}{l}\text { Fully } \\
\text { agree }\end{array}$ & 2.5 & 11.2 & 13.0 & 4.6 & 11.3 & 20.6 \\
\hline $\begin{array}{l}\text { Do not } \\
\text { know }\end{array}$ & 1.4 & 6.1 & 7.0 & 3.0 & 5.5 & 3.2 \\
\hline
\end{tabular}

A majority of the respondents considered unemployment and poverty to be caused by factors beyond individuals' own control, whereas about half of the respondents considered that social benefits in Finland are too lucrative and too easy to live on. To determine the extent to which responses to these questions possibly cluster into social blame and individual blame dimensions, we ran a factor analysis. The answers loaded on two distinct factors, and the loadings were strong and clear. On the one hand, questions 2, 3 and 5 formed their own 'social blame' component and questions 1, 4 and 6 clustered on the 'individual blame' attitudinal dimension. Based on these results, we formed two additive variables that were used in the regression models presented in Table 11.3. Cronbach's alpha was 0.628 for social blame and 0.679 for individual blame.

According to the analysis, gender is not significantly related to individual or social blame. Whereas age increases the propensity to emphasise social explanations, age is not significantly associated with individual blame. Although education and income are strongly correlated, the association between education and income vis-à-vis social blame and individual blame moves in different directions. While higher levels of education are positively associated with social blame and negatively associated with individual blame, the opposite is true for income. A closer analysis shows an interesting interaction: those with high educational attainments but low income tend to blame societal factors, 
whereas high-income earners with low educational achievements are more prone to blame individuals.

Both dimensions are correlated with political affiliations. If we use the voters for the National Coalition Party (the Conservatives) as a reference point, voters for all other parties - with the exception of the Centre Party - are significantly more against blaming the individual when background variables are controlled for. As far as social blame is concerned, only voters for the Social Democrats, the Left Alliance, and the Greens significantly deviate from the voters for the National Coalition.

\section{Attitudes on Deservingness, Item-specific Opinions, and Support for Basic Income}

The respondents could respond separately to each item-specific question about the anticipated consequences of introducing basic income in Finland. The response scale ranged from 0 (totally disagree) to 10 (totally agree). The means for each question are presented in the appendix (Table 11A.1). In the positive attributes, the means varied from a low of 5.71 for 'Social spending would decrease' to a high of 6.84 for 'Social security for short-term employees and the self-employed would improve'. In the negative item-specific opinions, the lowest mean 5.04 was for 'Because of duplicate benefits paid, the social security system would become more complicated' (mean $=5.04$ ) and the highest one for 'Responsibilities between individuals and the state would become blurred' (mean $=5.53$ ). The means of the responses show that the positive aspects have a slightly stronger acceptance than the negative ones. The Finns seem to have at least a lukewarm positive perception to the specific outcomes of basic income.

As in the case of the attitudinal dimensions of deservingness, we ran factor analysis to reduce the number of variables. The item-specific questions were loaded into two factors. Based on these results, we formed two additive variables with high consistency. Cronbach's alpha for the positive dimension was as high as 0.899 and for the negative dimension it was 0.857 . Thereafter, we ran regressions to study the connections between demographic background variables and political affiliations, and positive and negative item-specific opinions on basic income.

Regarding positive opinions, income had a negative and significant regression coefficient. Those in higher income groups were sceptical about the beneficial aspects of basic income. Gender, age, and education were not significant. In comparison with the voters for the Conservatives, voters for the Greens, the Left Alliance, and Social Democrats had significantly more positive views, whereas the Centre Party and the Finns Party 
Table 11.3 Regression analysis results on the determinants of support for basic income in Finland 2020: deservingness and opinions on the characteristics of basic income, coefficients and p-values

\begin{tabular}{lccccc}
\hline Model & M1 & M2 & M3 & M4 & M5 \\
\hline Social blame & 0.07 & & 0.05 & 0.06 & 0.06 \\
& $(<0.001)$ & & $(<0.001)$ & $(<0.001)$ & $(<0.001)$ \\
Individual blame & -0.10 & & -0.07 & -0.07 & -0.06 \\
& $(<0.001)$ & & $(<0.001)$ & $(<0.001)$ & $(<0.001)$ \\
Positive opinions & & 0.21 & 0.19 & 0.18 & 0.17 \\
& & $(<0.001)$ & $(<0.001)$ & $(<0.001)$ & $(<0.001)$ \\
Negative opinions & & -0.04 & -0.02 & -0.04 & -0.03 \\
& & $(<0.001)$ & $(0.216)$ & $(0.007)$ & $(0.047)$
\end{tabular}

Party affiliation

Conservatives (reference)

Finns Party

Centre

Greens

SDP

Notes: Model 1 considers only social blame and individual blame; Model 2 considers only positive and negative attributes of basic income; Model $3=$ Model $1+$ Model 2; Model $4=$ Model 3 and age, gender, income and education controlled for; and Model $5=$ Model 4 and political affiliation. The dependent variable is measured with the following survey question: 'What do you think about the following statement? A basic income should be introduced as a permanent part of the social security system in Finland: strongly agree (5), somewhat agree (4), neither agree nor disagree (3), somewhat disagree (2), strongly disagree (1) and cannot say (excluded from the analysis)'. 
voters did not deviate from the Conservatives. With regard to negative attributes, age and gender were significantly associated with critical opinions. Criticism increased when moving from younger to older age groups and from women to men. Education significantly decreases negative opinions, such as voting for the Left Alliance, Social Democrats, Centre or the Greens.

Table 11.3 gives a numeric summation of the discussion presented above. Attitudinal dimensions have a highly significant association with support for basic income, and the association remains significant, even when the two variables pertaining to item-specific opinions (Model 3) and political affiliations are added to the model and demographic background variables are controlled for (Model 5). Positive item-specific opinions are highly significantly linked to support for basic income in all the models, whereas negative perceptions have weaker connections and their coefficients sometimes lose significance. Of the political affiliations depicted in Model 5, only voting for the Greens and the Left Alliance is a significant determinant of a positive basic income opinion.

The first, attitudinal model explains 8 percent of the variation (Adj. $R^{2}$ ) in the support for basic income. The second model, with specific characteristics of basic income as independent variables, performs better and increases the variance explained to 18 percent. If we combine both the attitudinal and item-specific variables, as in Model 3, the $R^{2}$-values increase further. However, introducing demographic controls (Model 4) or political affiliations of the respondents (Model 5) did not substantially increase the variance explained.

Based on this study, we cannot establish whether values, attitudes, and opinions come first followed by party affiliation, whether it is vice versa, or whether they are formed simultaneously. The cross-sectional and one-dimensional analysis carried out above cannot reveal all the multidimensional interactions between various demographic, socio-economic, and other background variables, attitudes, item-specific opinions of basic income, and political affiliations. In the concluding section, we attempt to provide a heuristic description of the possible multidimensional relationships of different factors behind the popular support for basic income. 


\section{CONCLUSIONS AND DISCUSSION}

This chapter focused on different factors explaining the support for basic income in Finland. We used data from two opinion surveys to explore the potential determinants of popular support.

We first analysed how income inadequacy and insecure employment relations are associated with the likelihood of supporting or opposing basic income. Our analyses showed that fixed-term full- and part-timers are more likely to support basic income than are those who have full-time and permanent contracts or part-timers with permanent jobs. This result fits our expectations: own experience of insecurity in the labour market is likely to affect how people view the desirability of basic income. According to the results, inadequate income increases the probability of supporting basic income.

Opinions on policy issues are also based on individuals' value preferences, which, in turn, are related in a number of ways to how people perceive societal problems. Previous studies show that support for social policy is strongly linked to the so-called 'deservingness' principle, that is, who should get what and on what grounds (van Oorschot et al., 2017). In the second part of our study, we focus on this value-based attitudinal dimension. Individual blame, pertaining to the view that social problems and welfare needs are a result of individuals' own actions. Social blame, meanwhile, refers to the societal roots of individual problems. These two dimensions appear to have significant ramifications for the support for basic income. Those who emphasise individual reasons tend to be sceptical of unconditional transfers, whereas the opposite is true for those who emphasise social blame: they tend to support basic income. The two dimensions of deservingness are also strongly linked to an individual's political affiliation. Voters for left-wing parties and the Greens are more inclined to emphasise the social blame paradigm than are voters for other parties.

From the analyses of deservingness, we then moved to more specific questions on the possible outcomes of introducing a basic income scheme. Not surprisingly, proponents regard basic income as a solution to many problems of the present social security system and the world's societies, while opponents of basic income emphasise its possible detrimental behavioural effects. Similar to deservingness, these item-specific dimensions are important determinants of the support for basic income.

If we then compare the relative significance of various background factors, our tentative conclusion is that, on the one hand, socio-economic characteristics and labour market statuses of respondents are important explanatory factors for basic income, but on the other hand, attitudinal 
dimensions in general and deservingness criteria in particular are even more relevant.

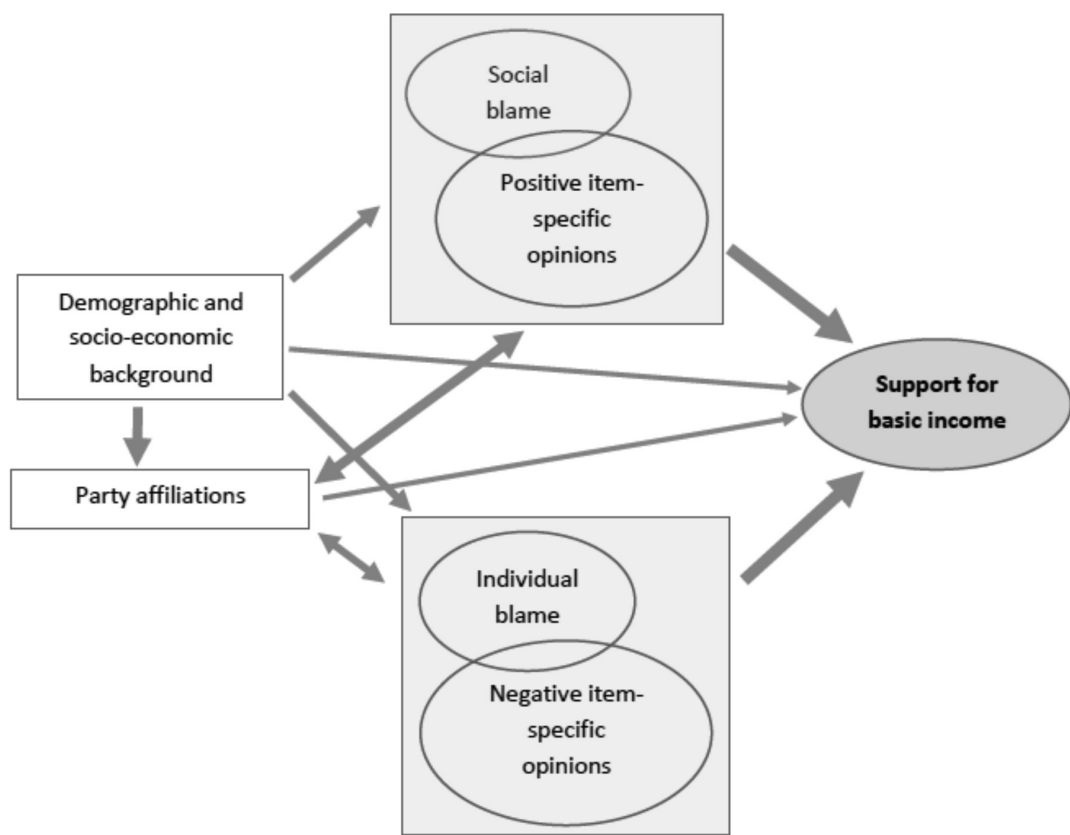

Figure 11.1 Summary of the relationships between demographic properties and labour market positions, political affiliations, views about deservingness, item-specific opinions concerning basic income, and support for basic income

Figure 11.1 summarises our previously presented analyses. The thickness of an arrow indicates the strength of the relationship between the study variables. Demographic factors and socio-economic status are linked to party preferences. Those with higher positions in the social hierarchy tend to vote for right-wing parties, adhere to individual blame explanations, and have negative views of the possible outcomes of basic income. Those on the lower ladder of the social hierarchy and uncertain labour market positions are more likely to emphasise societal reasons for individuals' problems and evaluate basic income in positive terms. As indicated by thicker arrows, the attitudinal dimensions are strongly associated with the likelihood of support for basic income. Double-headed thick arrows describe the dialectic interaction between values, attitudes, and item-specific opinions. 
To more reliably study these linkages and even establish causality between the variables, we would need longitudinal data. Collecting such data is a task for future studies.

\section{REFERENCES}

Airio, I., Kangas, O., Koskenvuo, K., and Laatu, M. (2016), 'Tasaveroon pohjautuviin perustulomalleihin suhtaudutaan varauksellisesti' ['Scepticism against flat-rate tax based basic income models'], available at https://tutkimusblogi.kela.fi/arkisto/2942 (accessed 15 December 2020).

Andersson, J. O. and Kangas, O. (2004), 'Popular support for basic income in Sweden and Finland', in Standing, G. (ed.), Promoting Income Security as a Right: Europe and North America, London: Anathem Press, pp. 289-302.

Andersson, J. O. and Kangas, O. (2005), 'Universalism in the age of workfare: Attitudes to basic income in Sweden and Finland', in Kildal, N. and Kuhnle, S. (eds), Normative Foundations of the Welfare State: The Nordic Experience, London: Routledge, pp. 112-29.

Bregman, R. (2017), Utopia for Realists and How We Can Get There, London: Bloomsbury.

De Wispelaere, J. and Stirton, L. (2013), 'The politics of unconditional basic income: Bringing bureaucracy back in', Political Studies, 61(4), 915-32.

Etzioni, A. and Platt, A. (2008), A Community-Based Guaranteed Income, Oxford: The Foundation for Law, Justice and Society, University of Oxford.

Fitzgerald, R. (2017), 'Assessing support for universal basic income', available at https://www.europeansocialsurvey.org/findings/singleblog.html?a=/findings/blog/ essblog0010.html (accessed 15 December 2020).

Frey, C. B. and Osborne, M. A. (2017), 'The future of employment: How susceptible are jobs to computerisation?', Technological Forecasting \& Social Change, 114, 254-80.

Goos, M., Manning, A., and Salomons, A. (2010), Explaining Job Polarization in Europe: The Roles of Technology, Globalization and Institutions, London: London School of Economics, CEP Discussion Paper, No. 1026.

Jacoby, W. G. (2006), 'Value choices and American public opinion', American Journal of Political Science, 50(3), 706-23.

Knotz, C. (2019), 'Why countries "get tough on the work-shy": The role of adverse economic conditions', Journal of Social Policy, 48 (3), 615-34.

Larsen, C. A. (2006), Institutional Logic of the Welfare Attitudes: How Welfare Regimes Influence Public Support?, Chippenham: Ashgate.

Murray, C. (1984), Losing Ground: American Social Policy 1950-1980, New York: Basic Books.

Niemelä, M. (2008), 'Perceptions of the causes of poverty in Finland', Acta Sociologica, 51(1), 23-40.

Pajarinen, M. and Rouvinen, P. (2014), Computerization Threatens One Third of Finnish Employment, Helsinki: ETLA Brief 22.

Parolin, Z. and Sjöland, L. (2020), 'Support for a universal basic income: A demandcapacity paradox?', Journal of European Social Policy, 30(1), 5-19.

Polanyi, K. (2001 [1944]), The Great Transformation: The Political and Economic Origins of Our Time, 2nd edn, Boston: Beacon Press. 
Pulkka, V.-V. (2018), 'Finland shares unconditional money, but the public view remains polarised', IPR Blog, available at http://blogs.bath.ac.uk/iprblog/2018/ 01/23/finland-shares-unconditional-money-but-the-public-view-remains-polarised/ (accessed 14 December 2020).

Rasinski, K. A. (1989), 'The effect of question wording on public support for government', Public Opinion Quarterly, 53(3), 388-94.

Rokeach, M. (1973), The Nature of Human Values, New York: Free Press.

Roosma, F. and Van Oorschot, W. (2020), 'Public opinion on basic income: Mapping European support for a radical alternative for welfare provision', Journal of European Social Policy, 30(2), 190-205.

Simanainen, M. and Kangas, O. (2020), 'Speaking to those who know it best: Does participation in an experiment explain citizens' attitudes to basic income?', Journal of International \& Comparative Social Policy, 36(3), 1-15.

Standing, G. (1999), Global Labour Flexibility, Houndmills: Macmillan.

Standing, G. (2011), The Precariat: The New Dangerous Class, London: Bloomsbury.

Standing, G. (2016), The Corruption of Capitalism. Why Rentiers Thrive and Work Does Not Pay, London: Bite Back Publishing.

Standing, G. (2017), Basic Income: And How We Can Make It Happen, London: Pelican Books.

Svallfors, S. (ed.) (2012), Contested Welfare States. Welfare Attitudes in Europe and Beyond, Stanford: Stanford University Press.

Van Oorschot, W. (2000), 'Who should get what, and why? On deservingness criteria and the conditionality of solidarity among the public', Policy \& Politics, 28(1), $33-48$.

Van Oorschot, W. V. and Halman, L. (2000), 'Blame or fate, individual or social?', European Societies, 2(1), 1-28.

Van Oorschot, W., Roosma, F., Meuleman, B., and Reeskens, T. (eds) (2017), The Social Legitimacy of Targeted Welfare: Attitudes to Welfare Deservingness, Cheltenham: Edward Elgar Publishing.

Van Parijs, P. (1995), Real Freedom for All: What (If Anything) Can Justify Capitalism?, Oxford: Oxford University Press.

Van Parijs, P. and Vanderborght, Y. (2017), Basic Income. A Radical Proposal for a Free Society and Sane Economy, Cambridge MA and London: Harvard University Press.

Zaller, J. R. (1992), The Nature and Origins of Mass Opinion, Cambridge: Cambridge University Press. 


\section{APPENDIX}

\section{Table 11A.1 Means for item-specific question on the characteristics of basic income ( $0=$ fully disagree, $10=$ fully agree)}

\begin{tabular}{ll}
\hline Item & Mean \\
\hline If basic income was implemented: & \\
Bureaucracy in social security would decrease & 6.52 \\
Social spending would decrease & 5.71 \\
It would be easier to accept short-term and low-paid jobs & 6.77 \\
Social security for short-term employees and the self-employed would improve & 6.84 \\
Tax avoidance and fraud in social security would decrease & 6.13 \\
The unemployed would have better possibilities to participate in society & 6.60 \\
Individuals' freedoms to decide about their own business would increase & 6.65 \\
Those most in need would be left without adequate support & 5.05 \\
Low-paid 'slave' labour would increase & 5.27 \\
Idleness and laziness would increase & 5.44 \\
Responsibilities between the individual and society would be blurred & 5.53 \\
Because of duplicate benefits, the social security system would become more & 5.04 \\
complicated & \\
The ability of the social security system to respond to changes in the labour market & 5.23 \\
would diminish & \\
\hline
\end{tabular}

